\title{
Use of the Hardware and Software Complex "Moscow Electronic School" in Training Teachers Working Under the International Baccalaureate Programmes
}

\author{
Vadim V. Grinshkun and Natalia A. Usova* \\ Moscow City University \\ 29 Sheremetievskaya Str., Moscow, 127521, Russia
}

Received 13.07.2019, received in revised form 26.08.2019, accepted 09.09.2019

The results of a study of the influence quantity of the educational resources of the Moscow Electronic School project on the professional qualities of teachers working under the International Baccalaureate programmes are presented in the article. A comparison of the effectiveness of teachers' work at Moscow schools of the International Baccalaureate system, who are enrolled in master's degree programmes at Moscow City University and use these resources as an object and a tool for education, was used as the main research method.

The proposed changes to the teacher training system, applied in connection with the possibility of their participation in the development and assessment of the Moscow Electronic School project's educational resources effectiveness are described in the article, an example of students' creative projects is provided.

In conclusion, based on the data available from the experiments, the trends of the described electronic resources' influence on the effectiveness of collective, creative and result-oriented educational activities, typical for the International Baccalaureate's approaches are identified. Conclusions about improving teachers' professional qualities in the field of educational, extracurricular and scientific-methodological activities are made.

Keywords: online educational resources, teacher training, informatization of education, International Baccalaureate, Moscow Electronic School.

Research area: theory and methods of teaching and upbringing (information science, computerization of education).

Citation: Grinshkun, V.V., Usova, N.A. (2019). Use of the hardware and software complex "Moscow electronic school" in training teachers working under the international baccalaureate programmes. J. Sib. Fed. Univ. Humanit. soc. sci., 12(9), 1622-1634. DOI: 10.17516/1997$1370-0487$.

(C) Siberian Federal University. All rights reserved

* Corresponding author E-mail address: usovana@mgpu.ru ORCID: 0000-0002-8204-9179 (Grinshkun)

This work is licensed under a Creative Commons Attribution-NonCommercial 4.0 International License (CC BY-NC 4.0). 


\section{Introduction}

Constant modernization of the Russian education system is also taking place considering advanced international pedagogical experience. Numerous education systems of the world gradually penetrate into Russian schools and universities, facilitating an increase in their educational activities efficiency. The International Baccalaureate Organization (IB), established in Switzerland over 50 years ago, has formed and continuously develops one of such education systems. Currently, this organization has repeatedly tested a universal academic programme with a common curriculum that gives an opportunity to the educational institutions in one country to consider education received in another country equivalent to the national one.

Schools, authorized in the IB system, can award their graduates diplomas that, without additional nostrification, are recognized in most countries of the world. When enrolling students, a lot of foreign universities prioritize the IB schools' graduates.

In schools of different countries, the IB system implements a total of four programmes for students aged 3 to 19 years (PYP - Primary Years Programme, MYP - Middle Years Programme, DP - Diploma Programme, CP — Career-Related Programme). Education according to such programmes is based on a combination of applying the IB approaches and taking into account the national education standards requirements. All the IB programmes are aimed at educating curious, erudite and empathic young individuals, capable of intercultural understanding and respect for other people. Using special methods, schools working in the IB system motivate students to be more active and compassionate, willing to improve their lifelong education, recognize the truth of other people, even if they have a different worldview (Gardner-McTaggart, 2016).

In 2019, 5139 schools in 156 countries of the world operate according to 6745 national variants of the IB programmes. And these figures are constantly growing. From 2012 to 2019, the number of such programmes adapted in different countries increased by $41.3 \%$. Since the early 90 s of the last century, leading Russian schools have been gradually transferring to the IB programmes. About 60 educational organizations in different cities of Russia currently implement one or several IB programmes. 35 educational IB centers operate in Moscow, forming a unique pedagogical community, functioning according to the coordinated rules. The long-term educational project of Moscow government "Moscow: International School of Quality" contributed the development of kindergartens and the IB schools in the capital of Russia.

Teachers working in the IB system must have additional professional qualities. Generally speaking, they have to master various advanced approaches of international 
education, including differential education; the use of the latest information technologies, projective pedagogy elements and specialized assessment systems; focus on results, personal qualities, inter-personal skills and development of students' thinking. This indicates the feasibility of formation and constant updating the Russian system of teacher training for the IB schools.

At the same time, the development of Moscow educational organizations implementing the IB approaches is significantly affected by various educational projects of the city, one of which is the Moscow Electronic School (MES) project, which has been implemented since 2016, and which has now granted access to educational resources for all Russian schools. The development and implementation of the MES hardware and software complex implies equipping all Moscow schools with high-speed Internet access, replacing traditional blackboards with large interactive tablet panels, the use of the electronic class register and a school diary, as well as creating, supporting and collective replenishment of a special library of educational electronic resources (https://uchebnik.mos.ru). Such a collection contains electronic versions of traditional textbooks, graphic images, audio and video clips, electronic means for verifying learning outcomes and electronic lesson plans (training materials for a teacher, demonstrations for the entire class and individual educational materials for school students). Due to the MES project, teachers have an opportunity to use their own materials and electronic resources of their colleagues when preparing for lessons and conducting them.

The presence of the abundance of new structured teaching materials, which development engaged many Moscow schoolteachers, surely cannot but influence the features of the development of all types of teachers and school students' educational activities. With this in mind, studies on the impact of the MES project on the effectiveness of training students in the context of introducing the IB approaches, as well as directions for the corresponding development of professional qualities and related teacher training systems for the IB schools are needed.

\section{Theoretical framework}

The conceptual approaches determined by the philosophy and ideology of the International Baccalaureate are detailed in the Internet resource of this world-wide educational organization (https://www.ibo.org). By their nature, they are close to the ideology of student-centered and project-based learning. Result-oriented performance, the use of criterion-oriented and formative assessment of students' academic 
achievements are fundamental. Examples of scientific publications and the IB research include studies by R. Brown, A. Gardner-McTaggart, E. B. Hacking, C. Blackmore, K. Bullock, T. Bunnell, M. Donnelly, S. Martin, as well as other educators and scientists (Brown, 2002; Gardner-McTaggart, 2016; Hacking et al., 2018). Their studies contain important recommendations for the development of creative, research, communicative and other qualities of school students, as well as suggestions for improving education systems within the framework of the IB programmes implementation. At the same time, the analysis of the possibilities of comprehensive informatization of training considering the specific features of the IB schools has not been carried out. The issues of the use of national collections of electronic educational resources and the corresponding teachers training for working under the IB programmes has not been studied. It should be noted that the IB approaches do not require students to study information technology when studying computer science, as it is done in Russian schools, but as part of studying design - design work involving the use of computer technology and its resources. In this regard, teachers of Russian schools face another significant task - the task of integrating computer science and design courses.

At the same time, a great theoretical and practical material on the general teachers training in the field of informatization of education has been accumulated. Studies by A. A. Kuznetsov， E. Bidaibekov， S. G. Grigoriev， V. V. Grinshkun, O. G. Smolyaninova, A. V. Slepukhina, T.N. Suvorova and other researches consider fundamental approaches that are invariant concerning the development of technologies to prepare teachers for their professional activities in the context of using tools for informatization of education (Kuznetsov, Suvorova, 2016; Bidaibekov et al., 2019; Bakhtibaeva et al., 2016; Smolyaninova, 2012; Smolyaninova, Bezyzvestnykh, 2019; Slepukhin, Semenova, 2013). These studies, in particular, substantiate the importance of comprehensive training of future and acting teachers how to search, develop and assess the quality and use of educational electronic resources application, taking into account the specific features of the implemented training systems for school students, which may also include the IB system.

In contrast to the indicated research areas, the pedagogical efficiency of the MES project resources does not have the proper scientific justification. I. M. Remorenko and V.V. Grinshkun in their studies proposed ways to develop this project, considering the search for areas of school subjects' demand in such resources, and described possible areas for improving hardware and software of the MES (Grinshkun, Remorenko，2017). A.I. Azevich，A. V. Gabova，D. A. Markova，D. Yu. Dobrotin 
and others researches studied various approaches to the design of certain types of the MES resources, emphasized the importance of using visual teaching materials and mentioned the necessity for additional teachers training (Azevich, 2016; Azevich, 2018; Gabova, Kapyrina, 2018; Markova, 2018; Smirnova, Dobrotin, 2018; Tsaplina, 2017). However, none of the published scientific studies addressed the issue of the MES resources applicability within the framework of the IB programmes implementation and the issue of finding ways to train teachers for the IB schools in the context of the MES project implementation.

\section{Statement of the problem}

The study described in the present article is devoted to considering the impact of the Moscow Electronic School project implementation on the possibility to develop the International Baccalaureate approaches in Russian educational organizations. It is evident that the appropriate teachers' qualification is the key to this development. In this regard, the main issue of the present study was finding ways to develop the teacher training system for the IB schools in the field of informatization of education and using the MES project resources as an object and means for teacher training. An additional task of the present study was to identify the degree of the MES resources application influence on the professional qualities and opportunities of the teachers working in the IB system.

\section{Methods}

Such methods as a comparative analysis of scientific sources and approaches to creating educational electronic resources, modeling and development of teacher training system in the field of informatization of education, assessment of the MES project resources selected or developed by the IB school teachers, experimental training of master's programmes students in pedagogical university, mathematical processing and analysis of such training outcomes, and comparison of the teachers' performance efficiency in Moscow IB schools were used in the present study.

\section{Discussion}

To solve the tasks set, preliminary modeling and subsequent development of a training system for the IB schoolteachers for the creation and use of the MES project educational electronic resources, were carried out within the framework of the present study. The existing system of professional training of such teachers as a part of the unique master's degree programme "Pedagogical Education" and the educational 
programme specialization "International Baccalaureate: Theory and Technology" was used as a basis for the study. Since 2014, teachers from Moscow schools and schools from other regions of Russia, most of whom work or have professional experience in the IB system, have been studying this programme at the Education Informatization Department of Moscow City University (MCU). Due to the international accreditation of this programme, in $2016 \mathrm{MCU}$ became the $32^{\text {nd }}$ university in the world with the right to issue graduates with the education certificates - the IB Educator Certificates in Teaching and Learning (PYP and MYP levels) recognized in all the IB organizations in the world. About 100 master students have been trained under this programme for five years, and 57 of them took part in the study.

The proposed model provided not the introduction of a new training course devoted to the study of the possibilities and specific features of working with the MES project, but consideration of certain aspects of the selection, development, assessment and application of such resources within the system of subjects, which included such training courses as "Information Technologies in Professional Activity", "Innovative Processes in Education", "Project Activities in the Educational Practice of the IB System", "Modern Teaching Technologies", "Assessment in the IB System", "Professional Development of the IB Teachers", "The IB Programmes and Technologies", "Teaching Subjects in a Foreign Language", "The Learning Resources in the IB System." The introduction of substantive and other components associated with the MES resources consideration was carried out within the framework of the aforementioned subjects in a comprehensive manner and was considered as a single system of a corresponding teacher training. Within the framework of such training, there was training in the MES project technologies and educational electronic resources, as well as the methodology for implementing teachers' educational and methodological activities, and educational and extracurricular activities for school students, taking into account the specific features of the IB approaches (the MES as a study object). At the same time, the hardware and software MES resources were used to train teachers (the MES as a learning tool), demonstrating examples and possibilities of using the MES when working in the IB system. Both approaches were applied interrelatedly.

To achieve the study objectives, the tasks of mastering this complex of subjects were expanded. This determined the corresponding expansion of the content, methods and means of training master students, which included:

1) information about positive and negative aspects of using the MES resources when implementing the IB approaches to teachers; 
2) formation of an idea about the kinds and areas of the efficient application of the MES hardware and software complex in the IB schools;

3) mastering the methods of search, development and publication of educational electronic resources when working with the MES library and designer;

4) informing students about the educational process needs and assessing learning outcomes, extracurricular, scientific and methodological, as well as organizational and managerial activities of the IB schools in the MES project resources;

5) forming knowledge about the requirements for the content resources of the MES project, the basic principles and technologies for assessing and moderating such resources;

6) training the IB schoolteachers the practical use of the MES educational resources in the process of the IB approaches implementation, including in the specific field of professional pedagogical activity;

7) acquaintance with the methods of sharing resources of the MES project and the international online resource of the IB Organization (https://www.ibo.org), which provides teachers with teaching materials and means for professional communication;

8) development of sustainable motivation for teachers - master's degree students to use MES resources and other means of informatization in training and subsequent professional activity within the framework of the IB system.

Within laboratory and practical work in the listed subjects, master's degree students - teachers of the IB schools carried out creative and project activities in different areas:

- analysis of the types, composition and features of the MES resources application in different types of educational activities to achieve the IB goals;

- selection of examples of positive and negative application of the MES resources when implementing the IB approaches;

- development and testing of the MES electronic resources contributing to the IB goals achievement in the educational process of the IB school (an example of such a task is given in Fig. 1);

- search and selection of resources from the MES library for teaching school students specific subjects using creative, project and communicative approaches of the IB (Markova, 2018);

- description, systematization and quality assessment of the MES educational resources used in the IB schools (Tsaplina, 2017); 


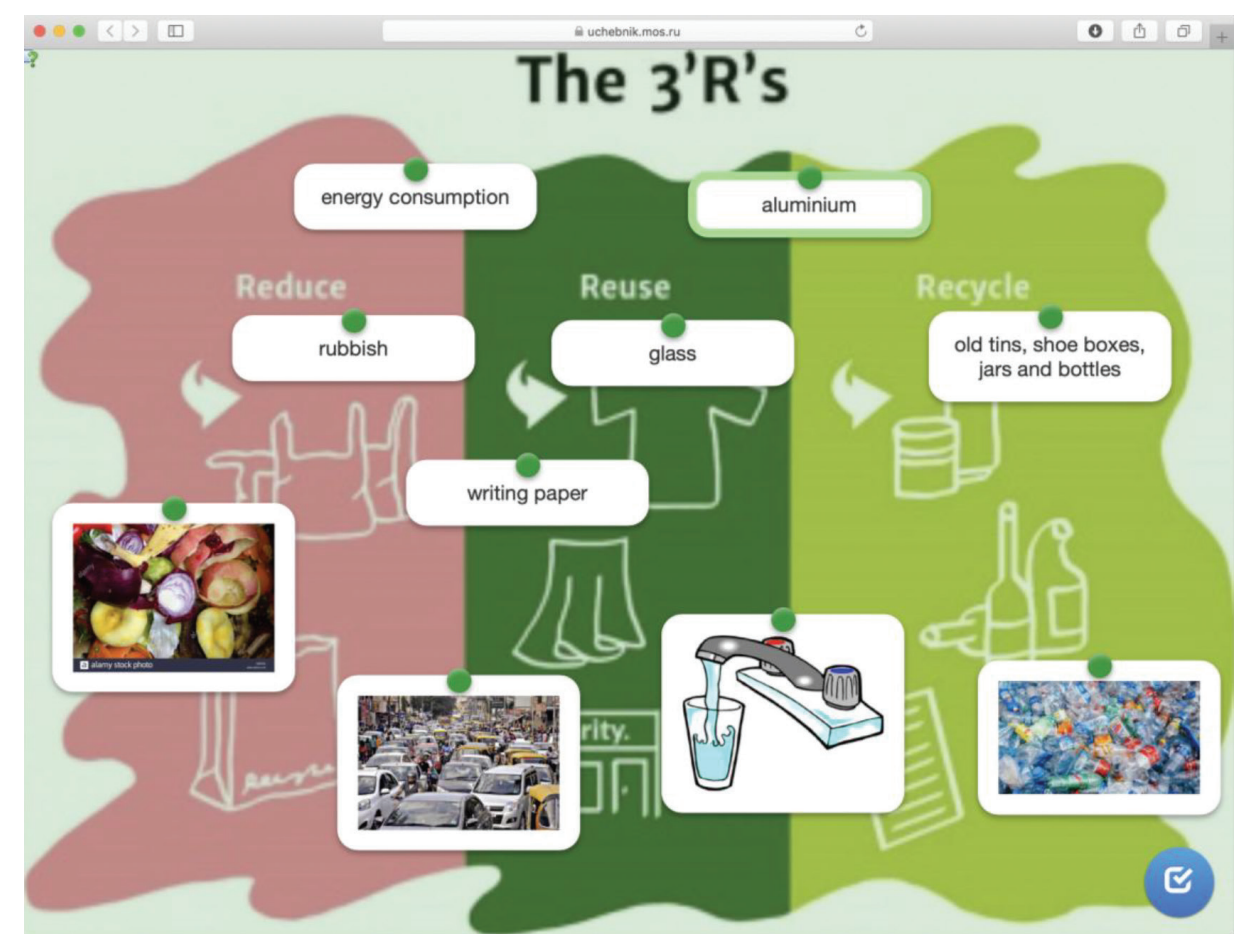

Fig. 1. The MES electronic resource created during experimental training by a teacher for teaching English in the IB system

- identification of methods and examples of telecommunication interaction between the IB system teachers in the context of joint activities and professional development based on the integrated use of the MES and the IB Organization Internet services;

- formation of the personal information environment of the IB schoolteacher using the MES services (case study of an electronic portfolio and an electronic register).

An assessment of the master's degree students' training results carried out within the university revealed a high degree of teachers' readiness to use the MES resources when implementing the IB approaches and efficiency of the proposed training system.

\section{Results}

Despite the proven positive nature of the changes made in the master's degree students training system, within the framework of the present study, the experiment was based on the data obtained as a result of the analysis of the professional and practical activities of the master's degree students - teachers of the IB schools in Moscow. 57 teachers, who took part in the experiment, were assessed and their results were 
reduced to a single five-point scale of indicators concerning their educational activity (average points of the IB school students obtained during tests and examinations), extracurricular activities (quantitative analysis of destructive incidents among the IB school students), and scientific and methodological activities (quantitative analysis of original pedagogical developments in the IB system: programmes, units, educational projects plans, assessment materials, exhibitions, etc.). The results obtained on the basis of the professional teachers' activities analysis in 2016-2019 are shown in Table 1.

Table 1. Dynamics of the professional teachers' activity efficiency in the IB schools before and after training using the MES project educational resources

\begin{tabular}{|l|c|c|c|c|c|c|}
\hline \multirow{2}{*}{ Efficiency level } & \multicolumn{2}{|c|}{ Educational activities } & \multicolumn{2}{c|}{ Extracurricular activities } & \multicolumn{2}{|c|}{$\begin{array}{c}\text { Scientific and } \\
\text { methodological activities }\end{array}$} \\
\cline { 2 - 7 } & $\begin{array}{c}\text { Without } \\
\text { the MES } \\
\text { resources }\end{array}$ & $\begin{array}{c}\text { With the MES } \\
\text { resources }\end{array}$ & $\begin{array}{c}\text { Without } \\
\text { the MES } \\
\text { resources }\end{array}$ & $\begin{array}{c}\text { With the MES } \\
\text { resources }\end{array}$ & $\begin{array}{c}\text { Without } \\
\text { the MES } \\
\text { resources }\end{array}$ & $\begin{array}{c}\text { With the MES } \\
\text { resources }\end{array}$ \\
\hline $\begin{array}{l}\text { Optimal level } \\
(4-5 \text { points) }\end{array}$ & $49 \%$ & $61 \%$ & $44 \%$ & $48 \%$ & $28 \%$ & $37 \%$ \\
\hline $\begin{array}{l}\text { Acceptable level } \\
(3-4 \text { points })\end{array}$ & $51 \%$ & $39 \%$ & $56 \%$ & $52 \%$ & $72 \%$ & $63 \%$ \\
\hline $\begin{array}{l}\text { Critical level } \\
(1-2 \text { points })\end{array}$ & \multicolumn{2}{|c|}{ Not detected } & \multicolumn{2}{c|}{ Not detected } & \multicolumn{2}{c|}{ Not detected } \\
\hline
\end{tabular}

The qualitative analysis of the results obtained gives on opportunity to conclude that the MES resources have a significant effect on improving the efficiency of the educational work of the IB schoolteachers. An increase of the indicator from $49 \%$ to $61 \%$ means that more than a half of the teachers reached the optimal level. It can be explained by the fact that most of the MES resources were created for the use in educational activities, and their development and use correspond to project, creative, interdisciplinary and communicative nature of all the IB programmes. An increase in this parameter also indicate of the positive impact of the MES resources application on the efficiency of training students when implementing the IB approaches.

A significant $9 \%$ increase in the share of teachers who demonstrated the optimal level of scientific and methodological activity is, first of all, associated with their mastery of the technologies for developing and systematization of electronic resources and electronic lesson plans for the MES project (Azevich, 2018). Such resources creation is an essential part of the methodological work of teachers in the IB system. 
Relatively low progress in the field of extracurricular activities is determined by still insignificant amount of resources of the MES project aimed at informatization of this type of pedagogical activity. It is recommended that educators and developers of the MES project pay increased attention to such resources.

\section{Conclusion}

The results obtained has led to several basic conclusions. It is necessary to develop a specialized training system for teachers working under the IB programmes in order to master the methods of creating and using electronic resources introduced in the Russian education system, which also include the MES project resources. The approaches to expanding the training system for the master's degree students - teachers of the IB schools, proposed in this regard, are efficient and significant from the practical point of view.

The interconnected use of the MES project resources as an object and a means of training teachers working under the IB programmes gives an opportunity to improve their professional qualities in the main types of educational activities and contributes to their preparation for using the latest tools for the informatization of educational. After such training teachers can develop missing online resources, use information technology to integrate international and domestic approaches to train school students, carry out project and research work with students, as well as conduct classes in foreign languages typical for the IB DP programmes. Due to the proposed approaches, the MES library is replenished with the resources necessary for the educational process in Russian IB schools.

The MES project requires further development, including in the area of developing methodological, extracurricular and educational resources, as well as resources that contribute to the personalization of training (Grinshkun, Remorenko, 2017). The subject heading of the MES library should be expanded to include additional subjects included into the international IB programmes.

There is a positive impact of the MES electronic resources application on the efficiency of collective, creative and results-oriented educational activities typical for the IB approaches.

\section{References}

Azevich, A.I. (2016). Vizualizatsiia pedagogicheskoi informatsii: uchebnometodicheskii aspect [Visualization of Pedagogical Information: Educational and 
Methodological Aspect]. In Vestnik Moskovskogo gorodskogo pedagogicheskogo universiteta. Seriia informatika i informatizatsiia obrazovaniia [Vestnik Moscow City University. Series Informatics and Informatization of Education], 3 (37), 74-82.

Azevich, A.I. (2018). Interaktivnyi urok v "Moskovskoi elektronnoi shkole": ot zamysla do voploshcheniia [Interactive Lesson at the Moscow Electronic School: From Idea to Implementation]. In Vestnik Moskovskogo gorodskogo pedagogicheskogo universiteta. Seriia informatika i informatizatsiia obrazovaniia [Vestnik Moscow City University. Series Informatics and Informatization of Education], 3 (45), 64-73.

Bakhtibaeva, S.A., Grinshkun, V.V., Berkimbaev, K.M., Turmambekov, T.A. (2016). Use of Information Technology in Teaching Semiconductors Physics. In Indian Journal of Science and Technology, 9 (19).

Bidaibekov, E., Grinshkun, V., Koneva, S., Baidrakhmanova, G. (2019). An Essential Change to the Training of Computer Science Teachers: The Need to Learn Graphics. In European Journal of Contemporary Education, 8(1), 25-42.

Brown, R. (2002). Mathematical Modelling in the International Baccalaureate, Teacher Beliefs and Technology Usage. In Teaching Mathematics and its Applications: An International Journal of IMA, 21 (2), 67.

Gabova, A.V., Kapyrina, T.A. (2018). Virtual'naia obrazovatel'naia sreda. Sozdaniie Moskovskoi elektronnoi shkoly [Virtual Learning Environment. Creation of the Moscow Electronic School]. In Russkiy iazyk i literatura: aktual'nye problemy teorii i praktiki prepodavaniia [Russian Language and Literature: Current Problems of Teaching Theory and Practice], 4-12.

Gardner-McTaggart, A. (2016). International Elite, or Global Citizens? Equity, Distinction and Power: The International Baccalaureate and The Rise of The South. In Globalisation, Societies and Education, 14 (1), 1-29.

Grinshkun, V.V., Remorenko, I.M. (2017). Frontiry "Moskovskoi elektronnoi shkoly" [Frontiers of the Moscow Electronic School]. In Informatika i obrazovanie [Informatics and Education], 7 (286), 3-8.

Hacking, E.B., Blackmore, C., Bullock, K., Bunnell, T., Donnelly, M., Martin, S. (2018). International Mindedness in Practice: The Evidence from International Baccalaureate Schools. In Journal of Research in International Education, 17 (1), 3-16.

Kuznetsov, A.A., Suvorova, T.N. (2016). Podgotovka uchitelei k razrabotke, otsenke kachestva i primeneniiu elektronnykh obrazovatel'nykh resursov [Teacher Training for the Development, Quality Assessment and Use of Electronic Educational Resources]. In Pedagogika [Pedagogy], 1, 94-101. 
Markova, D.A. (2018). Urok matematiki kak sochetanie traditsii i noveishikh tekhnologii obucheniia $\mathrm{v}$ usloviiakh realizatsii proekta MESh (iz opyta raboty) [A Mathematics Lesson As a Combination of Traditions and The Latest Teaching Technologies in the Context of the MES Project Implementation (From Practical Experience). In Nauka Rossii: Tseli i zadachi [Science of Russia: Goals and Tasks], 5-7.

Slepukhin, A.V., Semenova, I.N. (2013). Formirovanie professional'nykh kompetentsii studentov v protsesse razrabotki vizual'no-raz"yasnitel'nykh prezentatsii [Students' Professional Competencies Formation in the Process of Making Visual Explanatory Presentations]. In Pedagogicheskoe obrazovanie v Rossii [Pedagogical Education in Russia], 1, 134-140.

Smirnova, M.S., Dobrotin, D. Yu. (2018). Rezul'taty razrabotki i aprobatsii novogo soderzhaniia i form organizatsii pedagogicheskikh praktik budushchikh uchitelei nachal'noi shkoly s uchetom ispol'zovaniia MESh [Results of Development and Testing of New Content and Forms of Organizing Pedagogical Practices of Future Elementary School Teachers, Considering the use of the MES]. In Izvestiia instituta pedagogiki $i$ psikhologii obrazovaniia [Journal of the Institute of Educational Psychology and Pedagogy], 2, 19-27.

Smolyaninova, O.G., Bezyzvestnykh, E.A. (2019). Implementing Teachers’ Training Technologies at a Federal University: E-portfolio, Digital Laboratory, PROLog Module System. In International Journal of Online Engineering, 15 (4), 69-87, Available at: https://online-journals.org/index.php/i-joe/article/view/9288

Smolyaninova, O.G., (2012). Applied Bachelor Degree Programs as Technology Enhanced Education in the Innovative Russia (Implementation Experience in Krasnoyarsk Region). In Proceedings of the Iti 2012 34th International Conference on Information Technology Interfaces (ITI), 249-254, Available at: https://ieeexplore.ieee. org/document/6308013

Tsaplina, O.V. (2017). Podgotovka pedagogov k otsenke kachestva obrazovatel'nogo kontenta "Moskovskaya elektronnaia shkola" [Training Teachers for Assessing the Quality of Educational Content "Moscow Electronic School"]. In Izvestiia instituta pedagogiki $i$ psikhologii obrazovaniia [Journal of the Institute of Educational Psychology and Pedagogy], 3, 21-25. 


\title{
Использование аппаратно-программного комплекса \\ «Московская электронная школа» \\ при подготовке учителей, работающих по программам \\ Международного бакалавриата
}

\author{
В. В. Гриншкун, Н.А. Усова \\ Московский городской педагогический университет \\ Россия, 127521, Москва, ул. Шереметьевская, 29
}

\begin{abstract}
В статье представлены результаты исследования степени влияния образовательных ресурсов проекта «Московская электронная школа» на профессиональные качества педагогов, работающих по программам Международного бакалавриата. В качестве основного метода исследования использовано сравнение эффективности работы учителей в московских школах системы «Международный бакалавриат», обучаюшихся в магистратуре педагогического вуза с применением названных ресурсов в качестве объекта и средства обучения.

В статье описаны предложенные изменения, вносимые в систему подготовки педагогов в связи с появлением возможности их участия в разработке и оченке эффективности образовательных ресурсов проекта «Московская электронная школа», приведен пример творческих разработок обучающихся.

В заключении на основании данных, полученных экспериментальным путем, выявлены тенденции влияния описанных электронных ресурсов на эффективность коллективной, творческой, ориентированной на результат образовательной деятельности, характерной для подходов Международного бакалавриата. Сделаны выводы о повышении профессиональных качеств педагогов в области учебной, внеучебной и научнометодической деятельности.
\end{abstract}

Ключевые слова: образовательные электронные ресурсы, подготовка педагогов, информатизаиия образования, Международный бакалавриат, Московская электронная школа.

Научная специальность: 13.00 .02 - теория и методика обучения и воспитания (информатика, информатизация образования). 